\title{
Neurocognitive impacts of arbovirus infections
}

\author{
Marion Clé ${ }^{1}$, Patrick Eldin², Laurence Briant ${ }^{2}$, Annie Lannuze ${ }^{3,4}$, Yannick Simonin ${ }^{1}$, Philippe Van de Perre ${ }^{5}$, \\ André Cabié ${ }^{* *}$ and Sara Salinas ${ }^{* *}$
}

\begin{abstract}
Arthropod-borne viruses or arbovirus, are most commonly associated with acute infections, resulting on various symptoms ranging from mild fever to more severe disorders such as hemorrhagic fever. Moreover, some arboviral infections can be associated with important neuroinflammation that can trigger neurological disorders including encephalitis, paralysis, ophthalmological impairments, or developmental defects, which in some cases, can lead to long-term defects of the central nervous system (CNS). This is well illustrated in Zika virus-associated congenital brain malformations but also in West Nile virus-induced synaptic dysfunctions that can last well beyond infection and lead to cognitive deficits. Here, we summarize clinical and mechanistic data reporting on cognitive disturbances triggered by arboviral infections, which may highlight growing public health issues spanning the five continents.
\end{abstract}

Keywords: Arbovirus, Nervous system, Long-term sequelae, Cognition

\section{Background}

Neurological sequelae, including cognitive deficits, are emerging as potential long-term impairments associated with some arboviral infections. Among emerging viruses, some arboviruses are able to reach the central nervous system (CNS) and cause neuropathology. Accumulating evidence highlighted by follow-up studies is now showing that neurological symptoms such as memory, behavior, and other psychomotor deficits are found in patients, months after the initial infection and decrease in some cases their quality of life. The aim of this review is to provide a comprehensive view of the neurological impairments found in some arbovirus infections that can have long-lasting effects, and to correlate these observations with molecular and cellular studies aiming to decipher the effects of CNS arbovirus interaction.

\footnotetext{
*Correspondence: andre.CABIE@chu-martinique.fr; sara.salinas@inserm.fr ${ }^{6}$ INSERM CIC 1424, Infectious Disease and Tropical Medicine Unit, Martinique University Hospital, Université des Antilles EA4537, Martinique, France ${ }^{1}$ Pathogenesis and Control of Chronic Infections, INSERM, University of Montpellier, Etablissement Français du Sang, Montpellier, France Full list of author information is available at the end of the article
}

\section{Introduction}

Accumulating evidence illustrate now the fact that neurotropic viruses have developed numerous strategies to invade the brain and, depending on the mode of entry, cellular tropism and mechanism of infection, trigger a wide range of neuronal symptoms, which can lead in some cases to severe cognitive impairments [1-3]. Once in the brain, altered neuronal homeostasis triggered by long-term inflammatory microenvironment and/or viral replication can have dramatic effects and lead to cognitive disorders $[1,3$, 4]. For example, around $50 \%$ of human immunodeficiency virus (HIV)-infected patients are suffering from mild to severe neurological impairments in a syndrome called HIVassociated neurocognitive disorder (HAND) consisting of a range of cognitive deficits such as memory and attention disorders, motor and sensory impairment, mood and behavior changes and, in some extreme cases, dementia or HAD (HIV-associated dementia) [5]. HIV nervous system infection may also be linked to the etiology of some brain disorders such as amyotrophic lateral sclerosis [6] or Alzheimer's disease (AD) [7]. Another example is found among members of the Herpesviridae family, such as 
cytomegalovirus (CMV), which can be associated with neurodevelopmental defects, as well as herpes simplex virus 1 (HSV-1), which induces latent infection in the nervous system and in some cases can trigger encephalitis when reactivated. Notably, both viruses were found to induce significant cognitive impairment in the general population [8] and were also proposed to be involved in the etiology of AD $[9,10]$. "Hit and run" mechanisms leading to progressive neuronal pathology may be also considered, such as subacute sclerosing panencephalitis, a rare progressive neurological disease caused by complications associated with measles virus infection, which can have major impact including behavioral impairment cognitive decline and seizures [11].

Due to its peculiar architecture, the central nervous system (CNS) is relatively protected from toxic and pathogenic factors that can be found in the blood, and in this light, it is considered as immune-privileged. This however does not exclude that some toxins, viruses, bacteria, or parasites can access this organ and cause mild to severe impairment. This can be done directly through pathogen-mediated effects on neurons, or indirectly through inflammation-associated mechanisms when glial cells are affected for instance. To reach the central and peripheral nervous systems (PNS), pathogens have been selected throughout evolution for their ability to interact with various barriers and machineries [12, 13]. Notably, the blood brain barrier (BBB) is a tight endothelium that physically separates systemic circulation from the parenchyma. It is formed by closely interacting cells, which form the neurovascular unit (NVU): vascular endothelial cells that actually form the barrier, pericytes, astrocytes, and neurons (Fig. 1) [14]. Endothelial cells are closely interacting through tight and adherens junctions (TJ and AJ respectively), which ensure the (relative) impermeability of the barrier, although anatomical sites, such as the choroid plexus (CP), are more vulnerable due to their loose inter-endothelial cell junctions. Selective passage nevertheless exists as small lipophilic molecules, cytokines, and cells of the immune system can cross the BBB using different mechanisms such as transcytosis through receptor-mediated endocytosis, transport with efflux/influx pumps, transcellular lipophilic pathways, and transcellular diapedesis [15]. Direct infection of endothelial cells can also provide viral access to both sides of the barrier. Numerous viruses have been shown to directly and/or indirectly (e.g., through infection of cells of the immune system, a mechanism called "the Trojan horse") cross the BBB [16-19] (Fig. 1).

Many arboviruses (for arthropod-borne viruses), the majority of which are responsible for acute infections, can also access the CNS and infect a variety of cell types [20]. Because encephalitic arboviruses encompass numerous viruses belonging to various families, one cannot tend to generalize the (neuro) pathologies associated with these infections. However, these viruses are in the vast majority ribonucleic acid (RNA) viruses and transmitted by vectors such as mosquitoes, ticks, and sandflies during blood meals to a range of host including humans [21]. The replication cycle of arboviruses generally occurs in wild hosts such as birds and mammals. Vectors are then responsible for spreading infection among hosts in what is called an enzootic cycle [22]. In some situations, vectors can transmit viruses to animals that are not the natural host (i.e., do not replicate the virus), which are called accidental or dead-end hosts. This is the case for example for horses and humans following West Nile virus (WNV) or Usutu virus (USUV) infections [23, 24]. Some arboviruses such as dengue virus (DENV), Zika virus (ZIKV), and chikungunya virus (CHIKV) are less relying on viral amplification in wild animals and can be transmitted to humans during an urban cycle, and therefore are found associated with major epidemic outbreaks [21, 22]. Arboviral CNS infections can happen with a wide range of arboviruses including WNV, ZIKV, CHIKV, USUV, and Japanese encephalitis virus (JEV) among others, and cause diseases such as meningitis, encephalitis, meningoencephalitis, myelitis, and acute paralysis [20,25]. Because arboviral infections were mostly seen as acute, neurological symptoms, with the exception of neurodevelopmental impairment, were also largely reported on a short-time range. The recent ZIKV epidemic and the congenital syndromes associated (e.g., microcephaly [26]) suggest however that arboviral infections may have long-lasting effects on the nervous system. We review here the clinical and basic studies aiming to characterize the long-term effects of arboviral infections, in particular regarding cognitive performance.

\section{Acute and long-term cognitive deficits in arbovirus infections-a clinical perspective Arboviral infections and symptoms}

Clinically, arboviral infections are acute (viremia is typically few days long) and most frequently asymptomatic (60-80\% of patients) or trigger flu-like symptoms resulting in febrile state, mild to important fever, and, depending on the virus, can be accompanied by rash, conjunctivitis, myalgia, and cephalic pains [22]. In rare cases, severe symptoms such as hemorrhagic fever (e.g., for DENV and Crimean-Congo hemorrhagic fever virus (CCHMV) infections) or neuropathology (e.g., for WNV, Toscana virus, JEV, USUV, ZIKV...) can be found associated with arboviral infections. During epidemics however, even "moderate" symptoms (which still necessitate hospitalization) can be of a great burden, as it was well illustrated during the 2005-2006 CHIKV epidemic in the French island of La Réunion, which affected up to a third of the population and had a huge cost for the society $[27,28]$, or with DENV, which is 
A

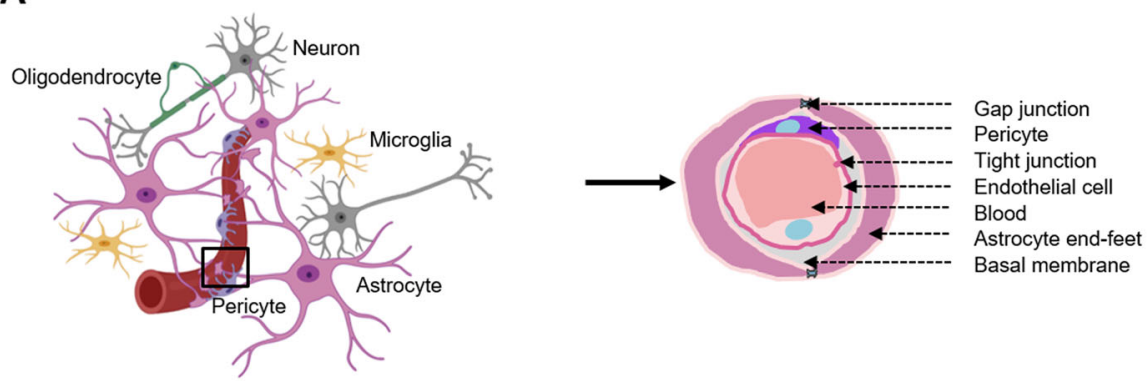

B

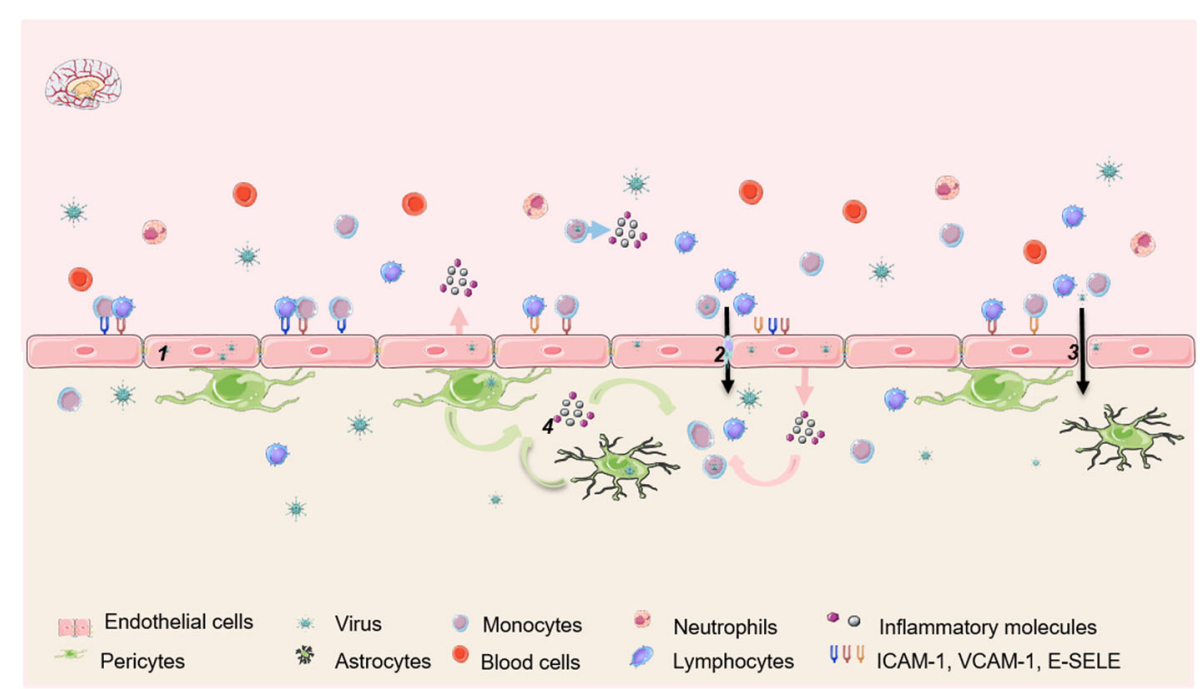

Fig. 1 The NVU and pathways of CNS viral entry through the BBB. a The NVU is formed by astrocyte end feet, perivascular microglia, neurons, as well as brain pericytes, which are embedded in the basement membrane and envelop the endothelial cells lining cerebral capillaries. $\mathbf{b}$ Description of possible mechanisms of CNS virus through the BBB. (1) Direct infection of endothelial cells that release viruses in the brain. (2) Infection of monocytes infiltrating the CNS by the Trojan horse mechanism. (3) Infection of endothelial cells that disrupt the BBB by the release of inflammatory mediators. (4) CNS cells participate in the disruption of CNS homeostasis by producing inflammatory molecules and allowing the recruitment of immune cells. Images created with BioRender.com and SMART-Servier Médical ART

present in 130 countries and put up to 2.5 billion people at risk each year [29]. This is particularly relevant for endemic arboviruses, which should be closely considered by clinicians [30], but given the current globalization of travelers and merchandises, as well as climate change, it is more than likely than emerging and remerging viruses will found "new" or naïve territories, similarly to what happened for ZIKV in South America or CHIKV in America [31, 32].

Moreover, long-term sequelae (lasting from weeks to years) can be found occurring after arboviral infections in some cases [33] (Table 1). CHIKV infections have been linked to lasting arthralgia and arthritis, among other symptoms, which directly impact the quality of life $[68,80,81]$. Ocular complications, reported for several arboviruses including WNV, CHIKV, DENV, and ZIKV among others, are often associated with long-term impairment [33, 43]. For instance, in ZIKV-infected adult patients suffering from visual impairment in the acute phase of infection, follow-up studies showed partial recovery as permanent lesions due to ZIKV infection may be likely to persist $[82,83]$. Recent data also point that ZIKV can persist in various body fluids for weeks to months, switching the paradigm of seeing (some) arbovirus infections as acute, towards more persistent or long-term infections [46, 84].

\section{Arboviral infections and neuroinflammation}

More worrying however, are the neurological impairments that can be directly triggered by arboviruses, both from congenital and adult infections (Table 1). CNS pathology during arbovirus infection can be due to direct neuronal infection, but also from indirect effects due to global neuroinflammation and post-infectious mechanisms that can occur in distinct anatomical regions. Regarding the brain, while inflammation isolated to the meninges triggers meningitis, viral replication in the brain 
Table 1 Neurological disorders associated with arboviral infections

\begin{tabular}{|c|c|c|c|}
\hline Virus & Neurological disorders & Long-term sequelae in children and in adults & References \\
\hline WNV & $\begin{array}{l}\text { Encephalitis, meningitis, meningoencephalitis, } \\
\text { and acute flaccid paralysis }\end{array}$ & $\begin{array}{l}\text { Neurological sequelae, confusion, seizure, memory } \\
\text { impairment, speech disability, depression, and } \\
\text { ocular complications }\end{array}$ & [34-42] \\
\hline DENV & $\begin{array}{l}\text { Encephalopathy, meningitis, stroke, cerebellar } \\
\text { syndrome, myelitis, and guillain-barré syndrome }\end{array}$ & $\begin{array}{l}\text { Neurological sequelae, mood-, personality-, } \\
\text { behavior- disorders, and ocular complications }\end{array}$ & {$[29,43-45]$} \\
\hline ZIKV & $\begin{array}{l}\text { Meningoencephalitis, guillain-barré syndrome, } \\
\text { microcephaly, and congenital Zika syndrome }\end{array}$ & $\begin{array}{l}\text { Mental retardation, seizure, epileptic behavior, } \\
\text { communication-, social cognition-, and mobility- } \\
\text { abnormalities, autism spectrum disorder, } \\
\text { intellectual disability, memory and learning } \\
\text { deficits, and ocular pathology }\end{array}$ & {$[46-62]$} \\
\hline JEV & $\begin{array}{l}\text { Encephalitis, aseptic meningitis and acute } \\
\text { flaccid paralysis }\end{array}$ & $\begin{array}{l}\text { Motor and language deficit, learning difficulties, } \\
\text { behavioral problems, mental retardation, } \\
\text { neurological-, neuropsychiatric-, and cognitive } \\
\text { sequelae }\end{array}$ & {$[63-67]$} \\
\hline CHIKV & $\begin{array}{l}\text { Encephalitis, myelopathy, neuropathy, } \\
\text { myeloneuropathy, myopathy, and paralysis }\end{array}$ & $\begin{array}{l}\text { Arthralgia, arthritis, neurological sequelae, } \\
\text { cognitive disturbance, and ocular complications }\end{array}$ & [68-73] \\
\hline TBEV & $\begin{array}{l}\text { Encephalitis, meningitis, meningoencephalitis, } \\
\text { and myelitis }\end{array}$ & $\begin{array}{l}\text { Cognitive sequelae, behavior-, memory-, and } \\
\text { language- dysfunctions }\end{array}$ & {$[74-77]$} \\
\hline EEEV, WEEV & Encephalitis & $\begin{array}{l}\text { Seizures, cognitive defects, psychiatric illness, } \\
\text { motor dysfunction, behavioral impairments, } \\
\text { and intellectual impairment }\end{array}$ & {$[78,79]$} \\
\hline
\end{tabular}

parenchyma results in encephalitis. Aseptic meningitis is classically defined as non-bacterial inflammation of the tissues lining the brain. Any inflammation or pathology that also involves the parenchyma is referred to as meningoencephalitis. "Neurotropic" (i.e., able to reach the CNS) arboviruses are classically associated with encephalitis [63, 78 , 85-87] but can also cause meningitis, for instance in infections by St. Louis encephalitis virus (SLEV) [88], tickborne encephalitis virus (TBEV) [89], DENV [90], WNV [91], CHIKV [92], ZIKV, Powassan virus (POWV), and Eastern Equine encephalitis virus (EEEV) [93]. During Toscana virus meningitis, serum levels of IFN- $\alpha$, IP-10, and eotaxin are significantly increased in the acute phase of infection in comparison with healthy controls [94], which could participate to an ensuing CNS infiltration of neutrophils, monocytes, and antiviral $\mathrm{CD}^{+}$lymphocytes. In patients suffering from encephalitis or meningoencephalitis due to WNV, perivascular and meningeal inflammation is found, both in the brain and in the spinal cord, which is associated with seizures and paralysis [20]. This illustrates the potential neuroinflammation found in some arboviral infections, which can cause acute and long-term neurological impairments [95].

\section{Congenital and pediatric arboviral infections and neurodevelopment}

Congenital arbovirus infections have been particularly reported for ZIKV, mostly due to the extent of the epidemic [47]. In this setting, microcephaly (which results in a decrease in head circumference and brain growth) and other cerebral malformations (called altogether congenital Zika syndrome or CZS) have been consistently reported throughout the American continent, but also elsewhere in the globe [47-51]. Moreover, retrospective studies in past epidemics, such as the one from French Polynesia, showed indeed that microcephaly and cerebral malformations were associated with ZIKV infection [52, 53]. Lissencephaly (malformation in the cortical structures of the brain) has also been reported in ZIKV-infected infants, which could result in mental retardation in affected children [54]. Importantly, there are now follow-up studies showing the effects from ZIKV-associated brain malformations or subtler damages. Such studies in infants with CZS confirmed strong neurological disabilities, in particular ocular and motor impairment, as well as epileptic manifestation [48, 55-60]. A study assessed over 1400 children of at least 1 year of age born from ZIKV-infected mothers and showed important rates of neurodevelopmental defects (up to $14 \%$ with seizure or, neurodevelopmental delays) [61]. Report on more than 200 children born from ZIKV-infected mothers in the region of Rio de Janeiro also showed important neurodevelopmental, including cognitive, impairment in around $30 \%$ of patients 2 years after birth [62]. The microcephaly status was shown to be altered in some children, either resolving or appearing [62]. Appearance or further development of neurological impairments can be also occur, consistent with observations that ZIKV can persist in infants after birth for a period of months (which is adding from the several weeks of ZIKV infection in utero) [54].

However, other arboviruses have been reported to be associated with pediatric and/or congenital neuronal disorders, in particular DENV [44], CHIKV [80, 69], and rarely WNV [96]. CHIKV infection is now well 
established as triggering serious neurological sequelae, particularly in children [70, 71]. Vertical transmission has been documented in several studies and highlights the risk of congenital infection associated with this virus [71-73]. Neurocognitive outcome of a La Réunion cohort of $33 \mathrm{CHIKV-perinatal} \mathrm{exposed} \mathrm{infants} \mathrm{showed}$ neurodevelopmental delays in around $50 \%$ of children compared to controls [69]. Cases of encephalopathy, microcephaly, and cerebral palsy were also described, some of them not detectable at birth and developing afterward, similarly to ZIKV-infected children [69]. Moreover, in a cohort of 87 children $\mathrm{CHIKV}^{+}$ (CHIKV RNA found in cerebrospinal fluid (CSF)) (55 infants less than 1 year old with an acute infectious syndrome and 32 children 2 to 10 years old with a convulsive attack or encephalopathy), evaluated 3.5 to 4.5 years after acute chikungunya, $20 \%$ of children presented developmental delays including cognitive impairment (our unpublished data).

Infants and children are also particularly at risk for DENV infection, potentially with severe forms [29]. Among these disorders, severe encephalopathy can be found (e.g. [45, 90],) but no long-term follow-up that suggests potential cognitive sequelae was reported as far as we know. This would definitely need to be addressed as DENV affects hundreds of thousand persons each year. Noteworthy, Rift valley fever virus (RVFV) is associated with vertical transmission and fetal demises in animals and with neurological and ocular impairment in humans [97]. Its epidemic potential is strongly considered as the WHO classified it as "severe emerging disease with potential to generate a public health emergency, and for which no, or insufficient, preventive and curative solutions exist" and is a reported as a category A priority pathogen [98]. Rare human vertical transmission have been reported, one of which resulted in infant death within a week [99]. Whether this is due to intrinsic properties of the virus (see below) or of poor surveillance diagnosis needs to be characterized. WNV vertical transmission does not seem a common feature but infections in children occur regularly [100]. These infections can give rise to meningitis, encephalitis, and acute flaccid paralysis, the latter of which can cause long-lasting disabilities but, curiously, neuroinvasive disease in children is less frequently found than in adults [100]. TBEV can also affect children but, similarly to WNV, infections are in general milder than in adults [74]. However, European cohort's studies in children demonstrate important rate of neurological and cognitive sequelae after TBEV infection [74, 75]. In the same light, other arboviral infections such as JEV or La Cross Virus (LACV) in children may be associated in some cases with neurological and cognitive sequelae [63, 87]. In a follow-up study over 2 years post-JEV infection in children showed mental retardation in over $20 \%$ of patients [64].

Altogether, these observations highlight the existence of potential risks associated with arboviral infections during pregnancy or in early life for child neuronal development [101]. In this context, it was also discussed that the neurodevelopmental defects associated with ZIKV infection in utero could potentially favor autism spectrum disorder [102]. Moreover, generally infectious encephalopathies in children represent important risks to develop neurological and cognitive sequelae [103], suggesting that arboviral infections in children may have severe consequences for the neuronal health of the individuals.

\section{Arboviral infections and acute and long-term cognitive impairment in adults}

Encephalitis, meningitis, and other neuronal complications following arboviral infections are also found in adults, with sometimes long-term cognitive impacts. In particular, neurological sequelae have been well described in WNV adult patients [34-39]. For instance, in a 1-year postinfection follow-up study of WNV patients who were diagnosed neuroinvasive disease, several neurological sequelae were reported including memory impairment, speech disability, and depression [34]. Similarly, mental health and social functioning were altered in some Canadian neuroWNV patients in a 2-year follow-up study [40] and in another 2 to 4-year follow-up study [41]. Moreover, in 1-3 and 8-11 year follow-up study of the Houston West Nile Cohort, new neurological symptoms developed in some patients, highlighting the need to closely monitor postencephalitic patients [42]. Similarly, the highly neurotropic JEV when infecting adults also led to significant increase in cognitive and behavior impairment in patients several years post-infection [65]. A prospective study of over 1300 Indian adult patients initially diagnosed with JEV infection highlighted the potential risk to develop neurological and cognitive sequelae after JEV infection: the authors showed in these patients of four epidemics between 1978 and 1989, neuropsychiatric and neurological sequelae at the time of discharge [66]. Some of these patients were then enrolled in follow-up studies (up to 14 years) that showed important neuronal sequelae including corticospinal impairment such as hyperkinetic movement and dystonia and seizures [67]. Psychiatric and psychological disturbances were also observed as long lasting: some patients were reported even though some recovery occurred [67]. Intellectual disability, memory, and learning deficits were also seen in a small proportion of patients [67].

Cognitive sequelae are also clearly associated with TBEV infection in adults; here, it can sometime be associated with neurological symptoms such as meningitis, encephalitis, and meningoencephalitis. Long-term 
follow-up studies highlighted the risk for cognitive sequelae: for instance, in a study following 36 Polish farmers diagnosed with TBEV infection during the 1994-2001 period, the authors reported cognitive impairment related to the pre-dementia stage of $\mathrm{AD}$ or memory and language dysfunction [76]. Similarly, in a Scandinavian adult cohort of 96 TBE patients, cognitive disorders such as changes in behavior and learning disabilities were reported in a follow-up study 2 to 15 years post-infection [77]. CHIKV can also lead to neurological disorders in adults, mainly encephalitis but also acute paralysis [71]. Importantly, neurological sequelae, including cognitive disturbance were found in adults who developed at the time of infection CNS disorders in a 2year follow-up examination [85]. Albeit neurological complications associated with ZIKV infections have been mainly described in pediatric cases, adults can also develop brain disorders [104]. For instance, behavioral changes were observed up to 15 weeks in a ZIKVinfected teenager [105].

Exposure to other emerging neurotropic arboviruses can have long-term deleterious effect on mental health as illustrated by a case of a 73-year-old patient infected with California Serogroup Virus who developed postencephalitic dementia and was transfered to a nursing home [106]. More than 6 months post-infection, the patient still scored low on a mental state examination $(11 / 30)$ [106]. Evenly worrisome, a follow-up study concerning Murray Valley encephalitis virus showed that even in patients discharged without evident sequelae, long-term cognitive disturbance such as depression and cognitive dysfunction were reported [107]. Alphaviruses have also been associated with neuronal impairment with long-term effects. Eastern, Western, and Venezuelan Equine encephalitis virus (EEEV, WEEV, VEEV) human infections have also been described, some of which led to cognitive sequelae $[78,108,109]$. Outbreaks of WEEV in the USA and in Canada in the 40-50s were proposed to be associated with important neuronal sequelae including behavioral impairments $[79,110]$. Follow-up studies of later WEEV outbreaks showed that some children and adult suffered from intellectual impairment [108].

\section{Impairment of neuronal functions by}

\section{arboviruses-molecular and cellular mechanisms}

Cognitive deficits can stem from different mechanisms, whether from impairment of neuronal development, neuronal dysfunction from a direct impairment of neuronal homeostasis (e.g., direct neuronal infection and function perturbation), or through indirect effects mediated by inflammatory molecules released by infected glia or immune cells. To understand the interaction and its effects between arboviruses and the nervous system, numerous studies aimed at characterizing the effect of infections on brain development, CNS entry mechanisms, and the cellular and molecular effects associated with brain infection and neuroinflammation.

\section{Mechanisms of neuronal development modulation by arboviruses}

Studies in animal models clearly showed that in utero or early post-natal ZIKV infections may have deleterious effect on neurodevelopment and trigger cognitive disorders in growing mice [111-113]. Importantly, ZIKV has been shown to potently cross the placenta using several mechanisms including infection of trophoblasts in the placenta, which further allow spread in the fetal nervous system [114].

Further studies showed that other arboviruses can infect human placenta and could be associated with fetal demise in animal models: a study showed that in human placental explants ZIKV, WNV, Mayaro virus (MAYV), and POWV, but not CHIKV, were able to replicate within different components of the tissue [115]. Similarly, RVFV can cross rat placenta and trigger deleterious effects on developing embryos [116]. Importantly, high viral load was detected in the pup brains [99]. Moreover, human placenta explants were also found permissive to RVFV replication [116], confirming the observations of human vertical transmission [99].

Numerous studies showed potent ZIKV infection of neuroprecursors and important neurodevelopmental defects (e.g. [117],). This infection is deleterious for the subsequent neuronal differentiation and the establishment of synapses [118]. Globally, in utero ZIKV infection led to cortical thinning resulting from neuronal growth defect and neuronal death [119]. This was accompanied by a reduction in neuronal network, suggesting important neurodevelopmental defects in developping animals, consistent with cognitive disturbances observed [112, 120]. Cell cycle dysfunction has been linked with ZIKV infection of neuroprogenitors $[119,121-123]$, which is likely to explain effects in neuronal differentiation and apoptosis as progenitor division is strictly necessary for neurogenesis. Due to extensive research following ZIKV epidemic and with the above observations in mind, researchers and clinicians agree around a consensus regarding the cause of ZIKVmediated microcephaly: potent infection of neuroprogenitors, coupled with cell death, differentiation, and neuronal network impairment are believed to be responsible for this congenital brain development disorder [124]. Regarding effects on the developing brain, much less data is available for other arboviruses. Similarly, JEV impairs subventricular zone neuroprogenitor proliferation and cell cycle progression through modulation of checkpoint proteins in wild-type (WT) mouse pups and in vitro [125]. Surprisingly, albeit clear 
neurodevelopmental and cognitive impairment have been shown in CHIKV-infected children [69], very little information is found on the physiopathology associated with these effects, albeit it was hypothesized that CHIKV could target neural progenitors and affecting neurogenesis [126]. Even though rare cases of congenital infections have been reported with WNV, in utero infection in a mouse model showed effect on brain development [115]. These studies corroborate observations in arboviral congenital or perinatal infections and their effect on neurodevelopment and cognitive functions.

\section{Mechanisms of arbovirus brain access}

To reach the adult CNS, neurotropic arboviruses use different mechanisms at the BBB such as direct viral infection of brain vascular endothelial cells or using cells of the immune system ("Trojan horse" pathway) [127]. It was proposed that WNV enters the CNS by infecting monocytes, dendritic cells, or macrophages that naturally cross the BBB $[128,129]$. Similarly, JEV and DENV have been shown to use such pathways [127]. Direct infection of endothelial cells may have different outcomes for viral access: some viruses such as ZIKV may not have important effect on BBB integrity but can be released through the basolateral compartment and reach the CNS [130]. Others may have more potent effects on $\mathrm{BBB}$ permeability through production of inflammatory cytokines, which can modulate BBB integrity. For instance, WNV by infecting directly brain vascular endothelial cells will lead to the production of inflammatory molecules that will disrupt BBB integrity and further allow virus CNS access through the Toll-like receptor (TLR)-3 response and tumor necrosis factors alpha (TNF- $\alpha$ ) secretion, resulting in a transient change BBB permeability [131]. DENV can directly infect human microvascular endothelial cells and induce cell apoptosis [132]. Moreover, modulation of TJ and AJ protein expression by arboviruses can also occur and increase viral and immune cell CNS access by paracellular pathway [133]. Studies also showed that neurotropic arboviruses can upregulate cell adhesion molecules in brain vascular endothelial cells, which in turn favor leukocyte recruitment and CNS invasion [134, 135]. Furthermore, some arboviruses can invade the brain at the blood-CSF interface [136-138]. Some flaviviruses are able to use the olfactory pathway to enter the CNS such as Murray Valley encephalitis virus and Saint Louis encephalitis virus. Others will use retrograde axonal transport to access it using peripheral nerves such as WNV [139-141].

\section{Arbovirus and interaction with the neurovascular unit}

Once in the brain, neurotropic arboviruses can also infect others types of NVU cells such as pericytes, astrocytes, neurons, and microglia and lead to general neuroinflammation and BBB impairment [14, 142]. Because astrocytes are mediators of neuroinflammation, these infections may further impair BBB homeostasis [143] and disrupt neuronal viability and induce cognitive dysfunction [144, 145]. Astrocytes can be infected by numerous arboviruses such as TBEV, WNV, ZIKV, and JEV [146]. In this context, WNV-infected astrocytes have been shown to secrete various inflammatory cytokines and matrix metalloproteinase (MMP), which will lead to BBB disruption [147, 148]. ZIKV-infected human astrocytes produce pro-inflammatory cytokines that induce neuroinflammation [149] and in mouse embryo brain, astrocytes-infected ZIKV induce progressive astrogliosis, which disrupts BBB properties and function [119]. Similarly, astrocytes infected with JEV lead to secretion of MMP, interleukin (IL)-6, and vascular endothelial growth factor (VEGF) and led to BBB destabilization [150]. JEVinfected astrocytes also led to an increase of the chemokine (C-X-C motif) ligand 10 (CXCL10) production, which modulates the migration of natural killer (NK) cells and monocytes into the CNS [151]. Moreover, arbovirus infection of astrocytes often results in the production of cytokines such as IL-6, TNF- $\alpha$, or IL1- $\beta$, which have been shown to modulate $\mathrm{BBB}$ permeability by several mechanisms, including downregulation or relocalization of junction proteins such as occludin and zona occludens (ZO)-1 [147, 152-154]. The NVU is also composed of pericytes, which support $\mathrm{BBB}$ homeostasis and function, and are emerging as key regulators in neuroinflammation [155, 156]. JEV, WNV, and ZIKV have been shown to target pericytes. JEV-infected pericytes in turn induce a degradation of TJ proteins such as zonula occludens (ZO)-1 protein and an upregulation of ubiquitin E3. Moreover, JEV-infected pericytes produce IL6, which disrupted the integrity of endothelial barrier $[157,158]$. Noteworthy, the $\mathrm{BBB}$ is also impaired during congenital infection as in utero ZIKV infection in mice led to abnormal vasculature, which triggered BBB leakage [119].

Arboviral interaction/modulation with the NVU may have important and potentially long-term effects as BBB and vasculature impairment are associated with cognitive disturbance either in an acute fashion, or in a longterm manner, for instance in aging [14]. Neurodegenerative disorders such as AD are multifactorial. In this context, vascular impairment has been proposed to contribute to the etiology of such diseases $[14,159]$. BBB dysfunction, coupled to pericyte degeneration may provoke toxic accumulation in the brain and neuronal dysfunction [14]. Similarly, repeated BBB injuries have been proposed to trigger neurodegeneration and neurocognitive dysfunction $[160,161]$.

\section{Arbovirus and modulation of synaptic function}

Some studies aimed to address synaptic homeostasis both during and after arboviral infections using animal 
models, which allow testing for cognitive disturbance. Cognition is a complex and multifactorial mechanism, whereupon synaptic plasticity plays a central role. This is occurring early in development when synaptogenesis and maintenance are taking place, and during adulthood with a balanced regulation of synapse formation and removal, collectively termed synaptic plasticity [162]. To these mechanisms can be added adult neurogenesis, in particular in the hippocampus, where new neurons are constantly generated and integrated in existing circuits to modulate learning and memory mechanisms [163]. In the context of arboviral infections, mature neurons can be directly infected by some arboviruses including ZIKV, WNV, TBEV, and JEV among others [139, 164-166]. For instance, ZIKV has been shown to replicate in mature neurons ex vivo in human cortex and in vivo in mouse models [165]. However, synaptic plasticity does not only involve only neurons but also interactions with glial cells such as astrocytes and microglia [162]. Microglia are key regulator of neurodevelopment, neuroinflammation, and BBB integrity [167]. An important mechanism involved in cognition is microglia-dependent synaptic removal, which allows synapse remodeling called synapse pruning [167]. This mechanism, when exacerbated, can cause cognitive dysfunction $[168,169]$. In an infection paradigm, activated microglia can be directly associated with neurodegeneration and cognitive defects [170].

Microglia infection/modulation has been described in several cases: ZIKV can lead to a potent inflammatory response in human fetal brain microglia [171]. JEV and DENV have also been shown to target microglia, which induce inflammatory environment [172, 173]. Using the rat as an animal model, authors showed that JEV led to behavioral changes including memory impairment that could be correlated with a decrease in the synaptic protein choline acetyl transferase (ChAT), a marker of dopaminergic neuron function [174]. Microgliadependent synaptic pruning has been proposed as a potential mechanism underlying neurocognitive impairment in patients recovering from WNV neuroinvasive disease. Indeed, observations in mice infected with a WNV mutant NS5 (E218A) suggest that the complement components ( $\mathrm{C} 3$ and $\mathrm{C} 3 \mathrm{aR})$ mediate presynaptic terminal loss in the hippocampi of mice that exhibit spatial learning defects during recovery from neuroinvasive disease [175] (Fig. 2). Microglia and recognition of C3 cleavage products by the complement receptor C3aR were shown responsible for this process [175]. Indeed, disease-recovered animals (who survived the neuroinvasive disease) showed learning deficits that were mirrored by the presence of engulfing microglia at synapses in the hippocampus. In particular, synaptic terminal of the C3 regions were reduced both in animal models and in biopsies of human patients [175]. Furthermore, in adult mice that recovered from WNV and ZIKV infections, activated microglia through the release of interferon (IFN)- $\gamma$ from infiltrating $\mathrm{T}$ cells were responsible of synaptic removal without repair in the case of $\mathrm{WNV}$, and with associated neuronal apoptosis for ZIKV [176, 177]. It was proposed that $\mathrm{CD}^{+} \mathrm{T}$ cells, through the release of inflammatory molecules and microglia activation and subsequent

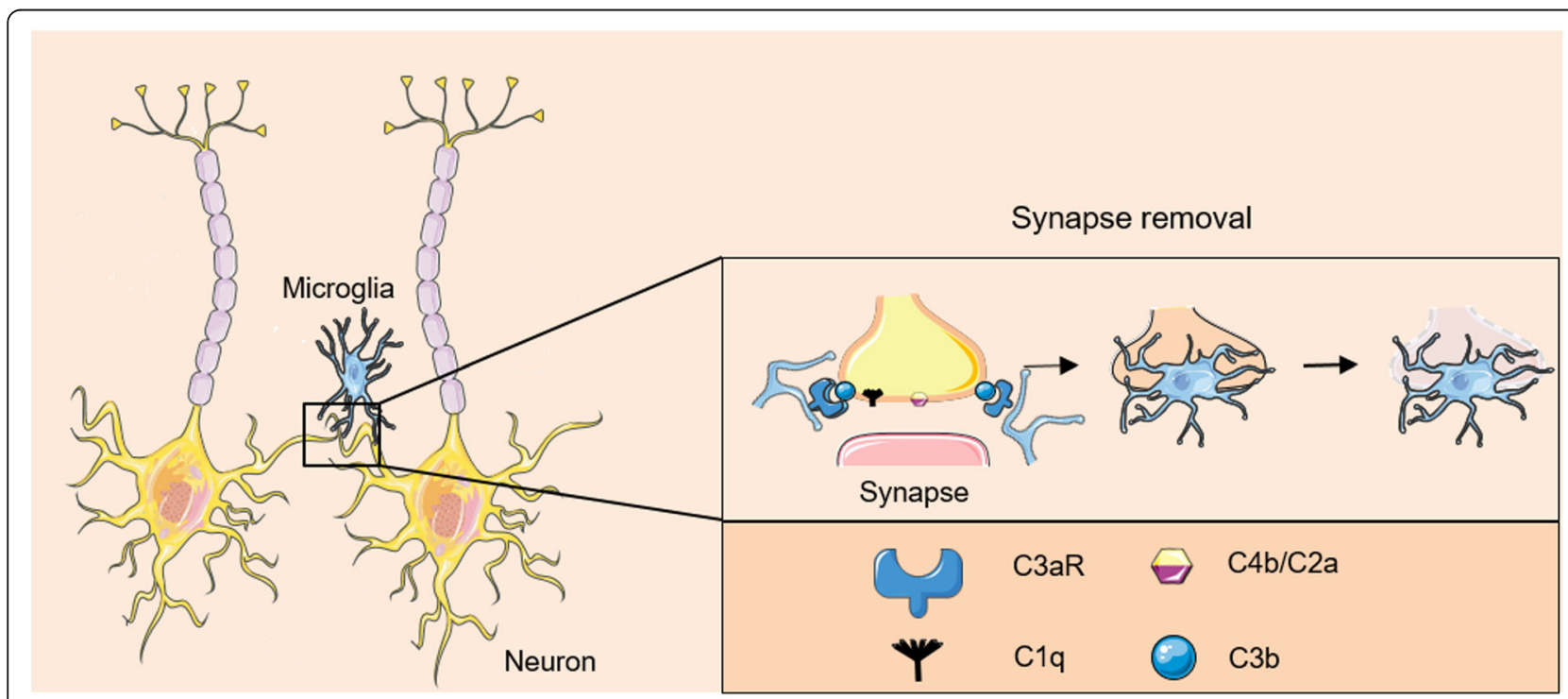

Fig. 2 Elimination of synapses by microglia via the complement pathway. Activation of microglial complement receptors during arboviral infection triggers the phagocytosis of synapses. Complement components C1q, C4b/C2a, and the C3 fragment (C3b) tag synapses. Microglial cells bind C3b through their CR3 receptors and partially phagocyte tagged synapses, resulting in selective synapse elimination. Images created with SMART- Servier Médical ART 
synaptic removal, were participating in the establishment of post-infection cognitive sequelae [176]. In another study, ZIKV replication in the hippocampus was shown to lead to the inhibition of long-term potential, a key mechanism regulating cognitive process such as memory [165]. The authors demonstrated the presence of activated microglia in close proximity to synaptic terminals and memory impairment in infected mice [165].

Some studies also point towards the modulation of adult neurogenesis by some arboviruses. During the acute phase of WNV infection, myeloid cell-derived IL1 alters the proliferation and differentiation fates of neural progenitor cells, leading to a shift from neurogenesis to astrogenesis [178]. Data indicate that the combinatorial effect of synapse loss and reduced neurogenesis can negatively impact hippocampal spatial learning and memory long beyond the initial episode of infection via a shift in sources of cytokines cells [178]. ZIKV-infection on human astrocytes led to disruption of pathways and cellular protein levels involved in synaptogenesis axonal guidance signaling [179]. This could also participate to ZIKV-induced impairment of neuronal circuits and network development [179]. ZIKV also targets adult neuroprogenitors and was shown to alter hippocampal neurogenesis by inhibiting neuroprogenitor development [180]. The modulation of adult neurogenesis, for instance during inflammatory process, has been clearly linked to cognitive disturbances [181]. Whether modulation of adult neurogenesis is a process commonly find in arboviral brain infection still remained to be addressed but could contribute, partly, to acute and potentially long-term cognitive impairment.

\section{Modulation of the neuro-epigenome by arboviruses}

Another crucial mechanism in brain development and maintenance and associated cognitive functions, are the regulation of neuroepigenetic modifications [182, 183]. The ability of some arboviruses to establish productive infection in brain cells, to evade their antiviral responses, and to impair neurodevelopment and neuronal homeostasis relies on their intrinsic capacity to evolve complex and multifaceted modes of interactions with their various cellular hosts. Among these modes of virus-host relationship, manipulation of the viral and cellular epigenome and epitranscriptome during infection has recently appeared as a complex and dynamic landscape of deoxyribonucleic acid (DNA) and RNA "decorations" that can be hijacked by arboviruses to promote their replication and could also participate to neuropathogenesis and long-term defects. ZIKV has been shown to alter the DNA methylome of neural progenitors, astrocytes, and differentiated neurons at genes that have been implicated in the pathogenesis of a number of brain disorders, most prominently mental retardation, autism, and schizophrenia [184]. The virus-mediated alteration of gene and gene products of DNA modifiers involved in the control of the dynamic cycle of methylation/demethylation of cytosine is currently investigated $[185,186]$. These studies might reveal how arboviruses may take over the dynamic $\mathrm{C} / 5 \mathrm{mC} / 5 \mathrm{hmC}$ switching process known to be critical for normal brain development and neuronal functions [187]. Manipulation of the viral and cellular epitranscriptome by positive-sense RNA viruses during infection may also control cellular and viral RNA stability and translatability drive subversion of the host and evasion of cellular surveillance systems [188, 189], preferentially promoting viral RNA translation, and eventually facilitating viral production. RNA modifications, including several nucleoside methylations, have long been known to be essential in the proper function of transfer ( $\mathrm{t}$ )RNA and ribosomal (r)RNA. Recent analysis of RNA post-transcriptional modifications (PTMs) in the context of arboviral infections has underscored their complex and dynamic nature on either cellular or viral RNAs. In infected target cells, erasure of N6-methyladenosine (m6A), the most abundant modification of messenger (m)RNA, was shown to be profitable for particle production for several flaviviruses including hepatitis C virus (HCV) and ZIKV [190, 191]. In contrast, Flaviviridae infection has recently been shown to increase the expression of specific cellular factors (such as RIOK3 and CIRBP) that turned to enhance viral infection, through the modification of the m6A levels on their corresponding mRNAs [192]. Moreover, virus-specific PTMs (such as dimethylcytosine species $\mathrm{m} 5 \mathrm{Cm}$ and $\mathrm{m} 44 \mathrm{C}$ ) were only present in the ZIKV and HCV RNA genomes isolated from virions and enhanced viral replication though the recruitment of the nuclear DEAD-box containing RNA helicase DDX6 [193]. In addition, members of the IFIT family of antiviral RNAbinding proteins restrict infection by cytoplasmic RNA viruses through their ability to strongly bind $5^{\prime}$ capped non-self mRNAs (cap0) thereby preventing their translation. Alphaviruses antagonize IFIT1 function directly by inhibiting association with viral RNA through the generation of stable secondary structures in the $5^{\prime}$-UTR (untranslated region) [194]. The control of RNA PTM could therefore play a critical role in the ability of RNA viruses to escape innate antiviral responses.

The remarkable diversity of PTMs that have already been identified on both cellular [192] and viral RNAs [193] suggests not only very broad functional consequences, but also the likelihood that the high degree of modification of the PTM landscape induced by RNA viruses, illustrated by the Zika-induced alteration of m6A topology in host mRNAs, may have deleterious effects on a wide range of mechanisms involved in the development and control of cognitive function. 


\section{Conclusions}

Acute or chronic neuroinflammation is emerging as a key mechanism in various neuronal disorders [95, 195]. Viruses are now strongly considered as potential environment factors favoring the onset of brain diseases. For instance, viral "hit and run" occurring during pediatric Measles infection can be linked with the appearance of neuronal disorders few years after the initial infection [11]. In this context, arboviral infections may have long-lasting effects on the nervous system, as a result of the direct interaction of viruses with cells of the brain, or, indirectly, because of the neuroinflammatory status found associated with the infections. However, the mechanisms underlying potential viral persistence and the contribution of neuroinflammation to CNS pathophysiology are unclear. Notably, other environmental factors such as toxins and chemicals are now well linked to neurological diseases. Among these multifactorial causes, one has to consider the burden of arboviral infections, in particular in endemic regions where annual epidemics are occurring. Cohort studies are still highly needed, in particular to study longterm sequelae.

\section{Abbreviations \\ AD: Alzheimer's disease; AJ: Adherens junctions; BBB: Blood brain barrier; CCHMV: Crimean-Congo hemorrhagic fever virus; ChAT: Choline acetyl transferase; CHIKV: Chikungunya virus; CMV: Cytomegalovirus; CNS: Central nervous system; CP: Choroid plexus; CSF: Cerebrospinal fluid; CXCL10: Chemokine (C-X-C motif) ligand 10; CZS: Congenital Zika syndrome; DENV: Dengue virus; DNA: Deoxyribose nucleic acid; EEEV: Eastern Equine encephalitis virus; HAD: HIV-associated dementia; HAND: HIV-associated neurocognitive disorders; HCV: Hepatitis C virus; HIV: Human immunodeficiency virus; HSV-1: Herpes simplex virus-1; IFN: Interferon; IL: Interleukin; JEV: Japanese encephalitis virus; LACV: La Cross Virus; MAYV: Mayaro virus; m6A: N6-methyladenosine; MMP: Matrix metalloproteinase; mRNA: Messenger RNA; NK: Natural killer; NVU: Neurovascular unit; PNS: Peripheral nervous system; POW: Powassan virus; PTM: Post-transcriptional modification; RVFV: Rift valley fever virus; RNA: Ribonucleic acid; TBEV: Tick-borne encephalitis virus; TJ: Tight junctions; TLR: Toll-like receptor; TNF-a: Tumor necrosis factors alpha; USUV: Usutu virus; VEEV: Venezuelan Equine encephalitis virus; WEEV: Western Equine encephalitis virus; WNV: West Nile virus; ZIKV: Zika virus; ZO-1: Zona occludens 1}

\section{Acknowledgements}

Not applicable

\section{Authors' contributions}

$M C, P E, A C$, and SS researched the literature and drafted the manuscript. $L B$, $A L, P V D P$, and YS critically reviewed and edited the work. All authors read and approved the final manuscript.

\section{Funding}

This work is supported by grants from Montpellier University of Excellence (ANR-16-IDEX-0006) and the Labex EpiGenMed "Investissements d'avenir" program (ANR-10-LABX-12-01).

Availability of data and materials

Not applicable

Ethics approval and consent to participate

Not applicable
Consent for publication

Not applicable

\section{Competing interests}

The authors declare that they have no competing interests.

\section{Author details}

${ }^{1}$ Pathogenesis and Control of Chronic Infections, INSERM, University of Montpellier, Etablissement Français du Sang, Montpellier, France. ${ }^{2}$ Institute of Research in Infectiology of Montpellier, CNRS, University of Montpellier, Montpellier, France. ${ }^{3}$ Neurology Unit, INSERM CIC 1424, Guadeloupe University Hospital, Université des Antilles, Pointe-à-Pitre, Guadeloupe, France. ${ }^{4}$ INSERM U1127, CNRS, UMR7225, Brain and Spine Institute, Sorbonne University Medical School, Paris, France. ${ }^{5}$ Pathogenesis and Control of Chronic Infections, INSERM, University of Montpellier, Etablissement Français du Sang, CHU Montpellier, Montpellier, France. ${ }^{6}$ INSERM CIC 1424, Infectious Disease and Tropical Medicine Unit, Martinique University Hospital, Université des Antilles EA4537, Martinique, France.

Received: 27 May 2020 Accepted: 17 July 2020

Published online: 10 August 2020

\section{References}

1. Ludlow M, Kortekaas J, Herden C, Hoffmann B, Tappe D, Trebst C, et al. Neurotropic virus infections as the cause of immediate and delayed neuropathology. Acta Neuropathol. Springer. Berlin Heidelberg. 2016;131: 159-84.

2. Agner SC, Klein RS. Viruses have multiple paths to central nervous system pathology. Curr Opin Neurol. 2018;31:313-7.

3. De Chiara G, Marcocci ME, Sgarbanti R, Civitelli L, Ripoli C, Piacentini R, et al. Infectious agents and neurodegeneration. Mol Neurobiol. 2012;46:614-38.

4. Mattson MP. Infectious agents and age-related neurodegenerative disorders Ageing Res Rev. 2004;3:105-20.

5. Thakur KT, Boubour A, Saylor D, Das M, Bearden DR, Birbeck GL. Global HIV neurology: a comprehensive review. AIDS. 2018;1.

6. Alfahad T, Nath A. Retroviruses and amyotrophic lateral sclerosis. Antiviral Res. Elsevier B.V: 2013:99:180-7.

7. Canet G, Dias C, Gabelle A, Simonin Y, Gosselet F, Marchi N, et al. HIV neuroinfection and Alzheimer's disease: similarities and potential links? Front Cell Neurosci. 2018;12:1-13.

8. Tarter KD, Simanek AM, Dowd JB, Aiello AE. Persistent viral pathogens and cognitive impairment across the life course in the third national health and nutrition examination survey. J Infect Dis. 2014;209:837-44.

9. Itzhaki RF. Herpes simplex virus type 1 and Alzheimer's disease: increasing evidence for a major role of the virus. Front Aging Neurosci. 2014;6:202.

10. Lurain NS, Hanson BA, Martinson J, Leurgans SE, Landay AL, Bennett DA, et al. Virological and immunological characteristics of human cytomegalovirus infection associated with Alzheimer disease. J Infect Dis. 2013;208:564-72.

11. Garg RK, Mahadevan A, Malhotra HS, Rizvi I, Kumar N, Uniyal R. Subacute sclerosing panencephalitis. Rev Med Virol. Rev Med Virol. 2019;29.

12. Koyuncu OO, Hogue IB, Enquist LW. Virus infections in the nervous system. Cell Host Microbe. Elsevier Inc.; 2013;13:379-93.

13. Salinas S, Schiavo G, Kremer EJ. A hitchhiker's guide to the nervous system: the complex journey of viruses and toxins. Nat Rev Microbiol. 2010;8:645-55.

14. Zhao Z, Nelson AR, Betsholtz C, Zlokovic B V. Establishment and dysfunction of the blood-brain barrier. Cell. Elsevier Inc.; 2015;163:1064-78.

15. Banks WA, Erickson MA. The blood-brain barrier and immune function and dysfunction. Neurobiol Dis. Elsevier B.V.; 2010;37:26-32.

16. Miner JJ, Diamond MS. Mechanisms of restriction of viral neuroinvasion at the blood-brain barrier. Curr Opin Immunol. Elsevier Ltd. 2016;38:18-23.

17. Zhang Y-L, Ouyang Y-B, Liu L-G, Chen D-X. Blood-brain barrier and neuroAIDS. Eur Rev Med Pharmacol Sci. 2015;19:4927-39.

18. Williams DW, Anastos K, Morgello S, Berman JW. JAM-A and ALCAM are therapeutic targets to inhibit diapedesis across the BBB of CD14 + CD16+ monocytes in HIV-infected individuals. J Leukoc Biol. 2015;97:401-12.

19. Dittmar S, Harms H, Runkler N, Maisner A, Kim KS, Schneider-Schaulies J. Measles virus-induced block of transendothelial migration of T lymphocytes and infection-mediated virus spread across endothelial cell barriers. J Virol. 2008;82:11273-82. 
20. Salimi H, Cain MD, Klein RS. Encephalitic arboviruses: emergence, clinical presentation, and neuropathogenesis. Neurotherapeutics. Neurotherapeutics. 2016;13:514-34.

21. Weaver SC, Reisen WK. Present and future arboviral threats. Antiviral Res. NIH Public Access. 2010;85:328-45.

22. Barzon L. Ongoing and emerging arbovirus threats in Europe. J Clin Virol. Elsevier. 2018;107:38-47.

23. Troupin A, Colpitts TM. Overview of West Nile virus transmission and epidemiology. Methods Mol Biol. 2016. p. 15-8.

24. Clé M, Beck C, Salinas S, Lecollinet S, Gutierrez S, Van de Perre P, et al. Usutu virus: a new threat? Epidemiol Infect. 2019;147:e232.

25. Tyler K. Emerging viral infections of the central nervous system: Part 1. Arch Neurol. 2009;66:939-48.

26. Kleber de Oliveira W, Cortez-Escalante J, De Oliveira WTGH, do Carmo GMI, Henriques CMP, Coelho GE, et al. Increase in reported prevalence of microcephaly in infants born to women living in areas with confirmed Zika virus transmission during the first trimester of pregnancy - Brazil, 2015. MMWR Morb Mortal Wkly Rep. 2016;65:242-7.

27. Soumahoro M-K, Boelle P-Y, Gaüzere B-A, Atsou K, Pelat C, Lambert B, et al. The Chikungunya epidemic on La Réunion Island in 2005-2006: a cost-ofillness study. Powers AM, editor. PLoS Negl Trop Dis. Public Library of Science; 2011;5:e1197.

28. de Valk H, Balleydier E, Solet J-L, llef D, Rachou E, Larrieu S, et al. A major epidemic of chikungunya virus infection on Réunion Island, France, 20052006. Am J Trop Med Hyg. The American Society of Tropical Medicine and Hygiene; 2007;77:727-731.

29. Li G-H, Ning Z-J, Liu Y-M, Li X-H. Neurological manifestations of dengue infection. Front Cell Infect Microbiol. 2017;7

30. Sigfrid L, Reusken C, Eckerle I, Nussenblatt V, Lipworth S, Messina J, et al. Preparing clinicians for (re-)emerging arbovirus infectious diseases in Europe. Clin Microbiol Infect. Elsevier Ltd. 2018;24:289-94.

31. JA G-S, GF R-A. Chikungunya virus: history, geographic distribution, clinical picture, and treatment. P R Health Sci J. P R Health Sci J; 2018;37.

32. Van Bortel W, Dorleans F, Rosine J, Blateau A, Rousseau D, Matheus S, et al. Chikungunya outbreak in the Caribbean region, December 2013 to March 2014, and the significance for Europe. Eurosurveillance. European Centre for Disease Prevention and Control; 2014;19:20759.

33. LaBeaud AD, Bashir F, King CH. Measuring the burden of arboviral diseases: the spectrum of morbidity and mortality from four prevalent infections. Popul Health Metr. 2011;9:1-11.

34. Carson PJ, Konewko P, Wold KS, Mariani P, Goli S, Bergloff P, et al. Longterm clinical and neuropsychological outcomes of West Nile virus infection. Clin Infect Dis. 2006;43:723-30.

35. Anastasiadou A, Kakoulidis I, Butel D, Kehagia E, Papa A. Follow-up study of Greek patients with West Nile virus neuroinvasive disease. Int J Infect Dis. International Society for Infectious Diseases; 2013;17:e494-e497.

36. Sadek JR, Pergam SA, Harrington JA, Echevarria LA, Davis LE, Goade D, et al. Persistent neuropsychological impairment associated with West Nile virus infection. J Clin Exp Neuropsychol. 2010;32:81-7.

37. Sejvar JJ. The long-term outcomes of human West Nile virus infection. Clin Infect Dis. 2007:44:1617-24.

38. Klee AL, Maidin B, Edwin B, Poshni I, Mostashari F, Fine A, et al. Long-term prognosis for clinical West Nile virus infection. Emerg Infect Dis. 2004;10: $1405-11$.

39. Petersen LR, Carson PJ, Biggerstaff BJ, Custer B, Borchardt SM, Busch MP. Estimated cumulative incidence of West Nile virus infection in US adults, 1999-2010. Epidemiol Infect. 2013;141:591-5.

40. Ouhoumanne N, Lowe A-M, Fortin A, Kairy D, Vibien A, K-Lensch J, et al. Morbidity, mortality and long-term sequelae of West Nile virus disease in Québec. Epidemiol Infect. 2018;146:867-74.

41. Samaan Z, McDermid Vaz S, Bawor M, Potter TH, Eskandarian S, Loeb M. Neuropsychological impact of West Nile virus infection: an extensive neuropsychiatric assessment of 49 cases in Canada. Klein RS, editor. PLoS One. 2016:11:e0158364.

42. Weatherhead JE, Miller VE, Garcia MN, Hasbun R, Salazar L, Dimachkie MM, et al. Long-term neurological outcomes in West Nile virus-infected patients: an observational study. Am J Trop Med Hyg. 2015;92:1006-12.

43. Merle H, Donnio A, Jean-Charles A, Guyomarch J, Hage R, Najioullah F, et al. Ocular manifestations of emerging arboviruses: dengue fever, Chikungunya, Zika virus, West Nile virus, and yellow fever. J Fr Ophtalmol. Elsevier Masson SAS. 2018:41:e235-43.
44. Paixão ES, Teixeira MG. Costa M da CN, Barreto ML, Rodrigues LC. Symptomatic dengue during pregnancy and congenital neurologic malformations. Emerg Infect Dis. 2018;24:1748-50.

45. Cam BV, Fonsmark L, Hue NB, Phuong NT, Poulsen A, Heegaard ED. Prospective case-control study of encephalopathy in children with dengue hemorrhagic fever. Am J Trop Med Hyg. 2001;65:848-51.

46. Chimelli L, Pone SM, Avvad-Portari E, Vasconcelos ZFM, Zin AA, Cunha DP, et al. Persistence of Zika virus after birth: clinical, virological, neuroimaging, and neuropathological documentation in a 5-month infant with congenital Zika syndrome. J Neuropathol Exp Neurol. 2018;77:193-8.

47. Platt DJ, Miner JJ. Consequences of congenital Zika virus infection. Curr Opin Virol. 2017;27:1-7.

48. Satterfield-Nash A, Kotzky K, Allen J, Bertolli J, Moore CA, Pereira IO, et al. Health and development at age 19-24 months of 19 children who were born with microcephaly and laboratory evidence of congenital Zika virus infection during the 2015 Zika virus outbreak — Brazil, 2017. MMWR Morb Mortal Wkly Rep. 2017;66:1347-51.

49. Chimelli L, Melo ASO, Avvad-Portari E, Wiley CA, Camacho AHS, Lopes VS, et al. The spectrum of neuropathological changes associated with congenital Zika virus infection. Acta Neuropathol. Springer. Berlin Heidelberg. 2017;133:983-99.

50. Reynolds MR, Jones AM, Petersen EE, Lee EH, Rice ME, Bingham A, et al. Vital signs: update on Zika virus-associated birth defects and evaluation of all U.S. infants with congenital Zika virus exposure — U.S. Zika Pregnancy Registry, 2016. MMWR Morb Mortal Wkly Rep. 2017;66:366-73.

51. WHO Zika situation report. Zika virus microcephaly Guillain-Barré syndrome. World Health Organization. 1 September 2016:2016.

52. Besnard M, Eyrolle-Guignot D, Guillemette-Artur P, Lastère S, Bost-Bezeaud $F$, Marcelis $L$, et al. Congenital cerebral malformations and dysfunction in fetuses and newborns following the 2013 to 2014 Zika virus epidemic in French Polynesia. Euro Surveill. 2016;21.

53. Cauchemez S, Besnard M, Bompard P, Dub T, Guillemette-artur P, Eyrolleguignot $D$, et al. Association between Zika virus and microcephaly in French Polynesia , 2013 - 15: a retrospective study. Lancet. Elsevier Ltd; 2016;6736:1-8.

54. Russo FB, Jungmann P, Beltrão-Braga PCB. Zika infection and the development of neurological defects. Cell Microbiol. 2017;19:1-6.

55. Pessoa A, van der Linden V, Yeargin-Allsopp M, Carvalho MDCG, Ribeiro EM, Van Naarden BK, et al. Motor abnormalities and epilepsy in infants and children with evidence of congenital Zika virus infection. Pediatrics. 2018; 141:S167-79.

56. van der Linden H. Carvalho MD, van der Linden V. Pessoa A, Carneiro ML, et al. Epilepsy profile in infants with congenital Zika virus infection. N Engl J Med: Lacerda KM; 2018.

57. Lockrow J, Tully H, Saneto RP. Epileptic spasms as the presenting seizure type in a patient with a new "O" of TORCH, congenital Zika virus infection. Epilepsy Behav Case Reports. 2019;11:1-3.

58. Marques FJP, Teixeira MCS, Barra RR, de Lima FM, Dias BLS, Pupe C, et al. Children born with congenital Zika syndrome display atypical gross motor development and a higher risk for cerebral palsy. J Child Neurol. 2019;34:81-5.

59. AL C, P V, T T, I B , C B, R L. Cerebral palsy in children with congenital Zika syndrome: a 2-year neurodevelopmental follow-up. J Child Neurol. J Child Neurol; 2020;35.

60. Pereira HVFS, Dos Santos SP, Amâncio APRL, de Oliveira-Szejnfeld PS, Flor EO, de Sales TJ, et al. Neurological outcomes of congenital Zika syndrome in toddlers and preschoolers: a case series. Lancet Child Adolesc Heal. Lancet Child Adolesc Health. 2020;4:378-87.

61. Lebov JF, Brown LM, MacDonald PDM, Robertson K, Bowman NM, Hooper SR, et al. Review: evidence of neurological sequelae in children with acquired Zika virus infection. Pediatr Neurol. Elsevier Inc.; 2018;85: $16-20$.

62. Nielsen-Saines K, Brasil P, Kerin T, Vasconcelos Z, Gabaglia CR, Damasceno L, et al. Delayed childhood neurodevelopment and neurosensory alterations in the second year of life in a prospective cohort of ZIKV-exposed children. Nat Med. Springer US. 2019;25.

63. Nanishi E, Hoshina T, Sanefuji M, Kadoya R, Kitazawa $K$, Arahata $Y$, et al. A nationwide survey of pediatric-onset Japanese encephalitis in Japan. Clin Infect Dis. 2019;68:2099-104

64. Kumar R, Mathur A, Singh KB, Sitholey P, Prasad M, Shukla R, et al. Clinical sequelae of Japanese encephalitis in children. Indian J Med Res. 1993;97:9-13 
65. Yin Z, Wang X, Li L, Li H, Zhang X, Li J, et al. Neurological sequelae of hospitalized Japanese encephalitis cases in Gansu province. China. Am J Trop Med Hyg. 2015;92:1125-9.

66. Sarkari NBS, Thacker AK, Barthwal SP, Mishra VK, Prapann S, Srivastava D, et al. Japanese encephalitis (JE). Part I: clinical profile of 1,282 adult acute cases of four epidemics. J Neurol. 2012;259:47-57.

67. Sarkari NBS, Thacker AK, Barthwal SP, Mishra VK, Prapann S, Srivastava D, et al. Japanese encephalitis (JE) part II: 14 years' follow-up of survivors. J Neurol. 2012;259:58-69.

68. de Andrade DC, Jean S, Clavelou P, Dallel R, Bouhassira D. Chronic pain associated with the Chikungunya fever: long lasting burden of an acute illness. BMC Infect Dis. 2010;10:31.

69. Gérardin P, Sampériz S, Ramful D, Boumahni B, Bintner M, Alessandri JL, et al. Neurocognitive outcome of children exposed to perinatal mother-tochild Chikungunya virus infection: the CHIMERE cohort study on Reunion Island. Powers AM, editor. PLoS Negl Trop Dis. Public Library of Science; 2014;:8:e2996.

70. Barr K, Vaidhyanathan V. Chikungunya in infants and children: is pathogenesis increasing? Viruses. Multidisciplinary Digital Publishing Institute; 2019;11:294.

71. Mehta R, Gerardin P, de Brito CAA, Soares CN, Ferreira MLB, Solomon T. The neurological complications of chikungunya virus: a systematic review. Rev Med Virol. 2018;28.

72. Contopoulos-loannidis D, Newman-Lindsay S, Chow C, LaBeaud AD. Mother-to-child transmission of Chikungunya virus: a systematic review and meta-analysis. PLoS Negl Trop Dis. 2018;12:1-20.

73. Gérardin P, Barau G, Michault A, Bintner M, Randrianaivo H, Choker G, et al. Multidisciplinary prospective study of mother-to-child Chikungunya virus infections on the island of La Réunion. Chretien J-P, editor. PLoS Med. Public Library of Science; 2008;5:e60.

74. Steffen R. Tick-borne encephalitis (TBE) in children in Europe: epidemiology, clinical outcome and comparison of vaccination recommendations. Ticks Tick Borne Dis. 2019;10:100-10.

75. Engman M-L, Lindström K, Sallamba M, Hertz C, Sundberg B, Hansson MEA, et al. One-year follow-up of tick-borne central nervous system infections in childhood. Pediatr Infect Dis J. 2012;31:570-4.

76. Gustaw-Rothenberg K. Cognitive impairment after tick-borne encephalitis. Dement Geriatr Cogn Disord. 2008;26:165-8.

77. Veje M, Nolskog P, Petzold M, Bergström T, Lindén T, Peker Y, et al. Tickborne encephalitis sequelae at long-term follow-up: a self-reported casecontrol study. Acta Neurol Scand. John Wiley \& Sons, Ltd (10.1111); 2016; 134:434-41.

78. Carrera J-P, Forrester N, Wang E, Vittor AY, Haddow AD, López-Vergès $S$, et al. Eastern equine encephalitis in Latin America. N Engl J Med. Massachusetts Medical Society. 2013;369:732-44.

79. MULDER DW, PARROTT M, THALER M. Sequelae of western equine encephalitis. Neurology. 1951;1:318-27.

80. van Aalst M, Nelen CM, Goorhuis A, Stijnis C, Grobusch MP. Long-term sequelae of chikungunya virus disease: a systematic review. Travel Med Infect Dis. 2017;15:8-22.

81. de Souza CG, da Costa JF, de Sousa Dantas D, de Abreu Freitas RP, Lopes $J M$, Okano AH. Evaluation of pain, functional capacity and kinesiophobia in women in the chronic stage of chikungunya virus infection: a crosssectional study in northeastern Brazil. Acta Trop. Acta Trop; 2019;199:104853.

82. Henry CR, Al-Attar L, Cruz-Chacón AM, Davis JL. Chorioretinal lesions presumed secondary to Zika virus infection in an immunocompromised adult. JAMA Ophthalmol. American Medical Association; 2017;135:386.

83. Manangeeswaran M, Kielczewski JL, Sen HN, Xu BC, Ireland DDC, McWilliams IL, et al. ZIKA virus infection causes persistent chorioretinal lesions. Emerg Microbes Infect. Nature Publishing Group; 2018;7:96.

84. Paz-Bailey G, Rosenberg ES, Doyle K, Munoz-Jordan J, Santiago GA, Klein L, et al. Persistence of Zika virus in body fluids — final report. N Engl J Med. Massachusetts Medical Society. 2018:379:1234-43.

85. Gérardin $\mathrm{P}$, Couderc $\mathrm{T}$, Bintner $\mathrm{M}$, Tournebize $\mathrm{P}$, Renouil $\mathrm{M}$, Lémant J, et al Chikungunya virus-associated encephalitis: a cohort study on La Réunion Island, 2005-2009. Neurology. 2016;86:94-102.

86. DellaBadia J, Jaffe SL, Singh J, Minagar A. An occipital lobe epileptogenic focus in a patient with West Nile encephalitis. Eur J Neurol. 2004;11:111-3.

87. McJunkin JE. de los Reyes EC, Irazuzta JE, Caceres MJ, Khan RR, Minnich LL, et al. La Crosse encephalitis in children. N Engl J Med. 2001:344:801-7.
88. Curren EJ, Lindsey NP, Fischer M, Hills SL. St. Louis encephalitis virus disease in the United States, 2003-2017. Am J Trop Med Hyg. Am J Trop Med Hyg; 2018;99:1074-1079.

89. Krbková L, Štroblová H, Bednárová J. Clinical course and sequelae for tickborne encephalitis among children in South Moravia (Czech Republic). Eur J Pediatr. Eur J Pediatr. 2015;174:449-58.

90. Marinho PES, Bretas de Oliveira D, Candiani TMS, Crispim APC, Alvarenga PPM, Castro FC dos $S$, et al. Meningitis associated with simultaneous infection by multiple dengue virus serotypes in children, Brazil. Emerg Infect Dis. 2017;23:115-8.

91. $N P, B M, A \cup, J P, L L, J N$, et al. Outbreak of West Nile virus infection among humans in Serbia, August to October 2012. Euro Surveill. Euro Surveill; 2013:18.

92. Saha S, Ramesh A, Kalantar K, Malaker R, Hasanuzzaman M, Khan LM, et al. Unbiased metagenomic sequencing for pediatric meningitis in Bangladesh reveals neuroinvasive chikungunya virus outbreak and other unrealized pathogens. MBio. mBio; 2019;10.

93. Wright WF, Pinto CN, Palisoc K, Baghli S. Viral (aseptic) meningitis: a review. J Neurol Sci. J Neurol Sci. 2019:398:176-83.

94. Rauch J, Zammarchi L, Corti G, Bartoloni A, Schlaphof A, Schmidt-Chanasit J, et al. Serum cytokine and chemokine changes during Toscana virus meningitis. Med Microbiol Immunol. Med Microbiol Immunol. 2019;208:727-30.

95. Hong H, Kim BS, Im H. Pathophysiological role of neuroinflammation in neurodegenerative diseases and psychiatric disorders. Int Neurourol J. 2016; 20:52-7.

96. Rasmussen SA, Meaney-Delman DM, Petersen LR, Jamieson DJ. Studying the effects of emerging infections on the fetus: experience with West Nile and Zika viruses. Birth Defects Res. 2017;109:363-71.

97. Ikegami T, Makino S. The pathogenesis of rift valley fever. Viruses. 2011;3: 493-519.

98. Hartman A. Rift Valley fever. Clin Lab Med. 2017;37:285-301.

99. Arishi HM, Aqeel AY, Al Hazmi MM. Vertical transmission of fatal Rift Valley fever in a newborn. Ann Trop Paediatr. 2006;26:251-3.

100. Barzon L, Pacenti M, Sinigaglia A, Berto A, Trevisan M, Palù G. West Nile virus infection in children. Expert Rev Anti Infect Ther. 2015;13:1373-86.

101. Charlier C, Beaudoin MC, Couderc T, Lortholary O, Lecuit M. Arboviruses and pregnancy: maternal, fetal, and neonatal effects. Lancet Child Adolesc. Heal. 2017. p. 134-46.

102. Vianna P. Gomes J do A, Boquett JA, Fraga LR, Schuch JB, Vianna FSL, et al. Zika virus as a possible risk factor for autism spectrum disorder: neuroimmunological aspects. Neuroimmunomodulation. 2018;25:320-7.

103. Khandaker G, Jung J, Britton PN, King C, Yin JK, Jones CA. Long-term outcomes of infective encephalitis in children: a systematic review and meta-analysis. Dev. Med. Child Neurol. 2016. p. 1108-15.

104. da Silva IRF, Frontera JA, Bispo de Filippis AM, Nascimento OJM do. Neurologic complications associated with the Zika virus in Brazilian adults. JAMA Neurol. American Medical Association; 2017;74:1190.

105. Zucker J, Neu N, Chiriboga CA, Hinton VJ, Leonardo M, Sheikh A, et al. Zika virus-associated cognitive impairment in adolescent, 2016. Emerg. Infect. Dis. 2017. p. 1047-8.

106. Webster D, Dimitrova K, Holloway K, Makowski K, Safronetz D, Drebot MA. California serogroup virus infection associated with encephalitis and cognitive decline, Canada, 2015. Emerg Infect Dis. 2017;23:1423-4

107. Selvey LA, Speers DJ, Smith DW. Long-term outcomes of Murray Valley encephalitis cases in Western Australia: what have we learnt? Intern Med J. 2016:46:193-201.

108. Earnest MP, Goolishian HA, Calverley JR, Hayes RO, Hill HR. Neurologic, intellectual, and psychologic sequelae following western encephalitis: a follow-up study of 35 cases. Neurology. 1971;21:969.

109. Ronca SE, Dineley KT, Paessler S. Neurological sequelae resulting from encephalitic alphavirus infection. Front Microbiol. Frontiers. 2016;7:959.

110. PALMER RJ, FINLEY KH. Sequelae of encephalitis; report of a study after the California epidemic. Calif Med. 1956;84:98-100.

111. Li C, Xu D, Ye Q, Hong S, Jiang Y, Liu X, et al. Zika virus disrupts neural progenitor development and leads to microcephaly in mice. Cell Stem Cell. Elsevier Inc:; 2016;1-7.

112. Shi Y, Li S, Wu Q, Sun L, Zhang J, Pan N, et al. Vertical transmission of the Zika virus causes neurological disorders in mouse offspring. Sci Rep. Nature Publishing Group; 2018;8:3541.

113. Wu Y-H, Cui X-Y, Yang W, Fan D-Y, Liu D, Wang P-G, et al. Zika virus infection in hypothalamus causes hormone deficiencies and leads to 
irreversible growth delay and memory impairment in mice. Cell Rep. ElsevierCompany.; 2018;25:1537-1547.e4.

114. Miner JJ, Cao B, Govero J, Smith AM, Fernandez E, Cabrera OH, et al. Zika virus infection during pregnancy in mice causes placental damage and fetal demise. Cell. Elsevier Inc.; 2016;1-11.

115. Platt DJ, Smith AM, Arora N, Diamond MS, Coyne CB, Miner JJ. Zika virusrelated neurotropic flaviviruses infect human placental explants and cause fetal demise in mice. Sci Transl Med. 2018;10:1-11.

116. McMillen CM, Arora N, Boyles DA, Albe JR, Kujawa MR, Bonadio JF, et al. Rift Valley fever virus induces fetal demise in Sprague-Dawley rats through direct placental infection. Sci Adv. 2018;4:eaau9812

117. Bayless NL, Greenberg RS, Swigut T, Wysocka J, Blish CA. Zika virus infection induces cranial neural crest cells to produce cytokines at levels detrimental for neurogenesis. Cell Host Microbe. Elsevier Inc.; 2016;20:423-8.

118. Rosa-Fernandes L, Cugola FR, Russo FB, Kawahara R, de Melo Freire CC, Leite PEC, et al. Zika virus impairs neurogenesis and synaptogenesis pathways in human neural stem cells and neurons. Front Cell Neurosci. Frontiers. 2019;13:64.

119. Shao Q, Herrlinger S, Yang S-L, Lai F, Moore JM, Brindley MA, et al. Zika virus infection disrupts neurovascular development and results in postnatal microcephaly with brain damage. Development. 2016:143:4127-36.

120. Stanelle-Bertram S, Walendy-Gnirß K, Speiseder T, Thiele S, Asante IA, Dreier $\mathrm{C}$, et al. Male offspring born to mildly ZIKV-infected mice are at risk of developing neurocognitive disorders in adulthood. Nat Microbiol. 2018;3: $1161-74$.

121. Ferraris $P$, Wichit $S$, Wolf B. Busso C. Open Biol: Zika virus causes supernumerary foci with centriolar proteins and impaired spindle positioning; 2017.

122. Onorati M, Li Z, Liu F, Sousa AMM, Nakagawa N, Li M, et al. Zika virus disrupts phospho-TBK1 localization and mitosis in human neuroepithelial stem cells and radial glia. Cell Rep. 2016;0:R151-R162.

123. Simonin $Y$, Loustalot F, Desmetz C, Foulongne V, Constant O, Fournier-Wirth $C$, et al. Zika virus strains potentially display different infectious profiles in human neural vells. EBioMedicine. The Authors. 2016;12:161-9.

124. Gorshkov K, Shiryaev SA, Fertel S, Lin Y-W, Huang C-T, Pinto A, et al. Zika virus: origins, pathological action, and treatment strategies. Front Microbiol. Frontiers. 2019;9:3252.

125. Das S, Basu A. Japanese encephalitis virus infects neural progenitor cells and decreases their proliferation. J Neurochem. 2008;106:1624-36.

126. Das T, Jaffar-Bandjee MC, Hoarau JJ, Krejbich Trotot P, Denizot M, Lee-PatYuen $\mathrm{G}$, et al. Chikungunya fever: CNS infection and pathologies of a reemerging arbovirus. Prog Neurobiol. Pergamon. 2010;91:121-9.

127. Mustafá YM, Meuren LM, Coelho SVA, de Arruda LB. Pathways exploited by flaviviruses to counteract the blood-brain barrier and invade the central nervous system. Front Microbiol. 2019;10.

128. Bai F, Kong K-F, Dai J, Qian F, Zhang L, Brown CR, et al. A paradoxical role for neutrophils in the pathogenesis of West Nile virus. J Infect Dis. 2010;202: 1804-12.

129. Paul AM, Acharya D, Duty L, Thompson EA, Le L, Stokic DS, et al. Osteopontin facilitates West Nile virus neuroinvasion via neutrophil "Trojan horse" transport. Sci Rep. Springer US; 2017;7:4722.

130. Papa MP, Meuren LM, Coelho SVA, Lucas CG de O, Mustafá YM, Lemos Matassoli F, et al. Zika virus infects, activates, and crosses brain microvascular endothelial cells, without Barrier Disruption. Front Microbiol. Frontiers; 2017:8:2557.

131. Wang T, Town T, Alexopoulou L, Anderson JF, Fikrig E, Flavell RA. Toll-like receptor 3 mediates West Nile virus entry into the brain causing lethal encephalitis. Nat Med. 2004;10:1366-73.

132. Vásquez Ochoa M, García Cordero J, Gutiérrez Castañeda B, Santos Argumedo L, Villegas Sepúlveda N, Cedillo BL. A clinical isolate of dengue virus and its proteins induce apoptosis in HMEC-1 cells: a possible implication in pathogenesis. Arch Virol. Springer Vienna. 2009;154:919-28.

133. Verma S, Lo Y, Chapagain M, Lum S, Kumar M, Gurjav U, et al. West Nile virus infection modulates human brain microvascular endothelial cells tight junction proteins and cell adhesion molecules: transmigration across the in vitro blood-brain barrier. Virology. 2009;385:425-33.

134. Velandia-Romero ML, Calderón-Peláez M-A, Castellanos JE. In vitro infection with dengue virus induces changes in the structure and function of the mouse brain endothelium. PLoS One. 2016;11:e0157786.

135. Roe K, Orillo B, Verma S. West Nile virus-induced cell adhesion molecules on human brain microvascular endothelial cells regulate leukocyte adhesion and modulate permeability of the in vitro blood-brain barrier model. Toborek M, editor. PLoS One. 2014;9:e102598.

136. Suen WW, Prow NA, Hall RA, Bielefeldt-Ohmann H. Mechanism of West Nile virus neuroinvasion: a critical appraisal. Viruses. Viruses. 2014;6:2796-825.

137. Puccioni-Sohler M, Rosadas C. Advances and new insights in the neuropathogenesis of dengue infection. Arq Neuropsiquiatr. Arq Neuropsiquiatr. 2015;73:698-703.

138. J K, B A, M H, EM H, J J, H S, et al. Zika virus infects pericytes in the choroid plexus and enters the central nervous system through the bloodcerebrospinal fluid barrier. PLoS Pathog. PLoS Pathog; 2020;16:e1008204.

139. Samuel M a, Wang H, Siddharthan V, Morrey JD, Diamond MS. Axonal transport mediates West Nile virus entry into the central nervous system and induces acute flaccid paralysis. Proc Natl Acad Sci U S A. 2007;104: 17140-17145.

140. Hunsperger EA, Roehrig JT. Temporal analyses of the neuropathogenesis of a West Nile virus infection in mice. J Neurovirol. Springer-Verlag. 2006;12:129-39.

141. Monath TP, Cropp CB, Harrison AK. Mode of entry of a neurotropic arbovirus into the central nervous system. Reinvestigation of an old controversy. Lab Invest. 1983;48:399-410.

142. Banks WA, Kovac A, Morofuji Y. Neurovascular unit crosstalk: Pericytes and astrocytes modify cytokine secretion patterns of brain endothelial cells. J Cereb Blood Flow Metab. 2017;0271678X1774079.

143. Michinaga S, Koyama Y. Dual roles of astrocyte-derived factors in regulation of blood-brain barrier function after brain damage. Int J Mol Sci. 2019;20:571.

144. Suzuki A, Stern SA, Bozdagi O, Huntley GW, Walker RH, Magistretti PJ, et al. Astrocyte-neuron lactate transport is required for long-term memory formation. Cell. Cell Press. 2011;144:810-23.

145. Habbas S, Santello M, Becker D, Stubbe H, Zappia G, Liaudet N, et al. Neuroinflammatory TNFa impairs memory via astrocyte signaling. Cell. Cell Press. 2015;163:1730-41.

146. Potokar M, Jorgačevski J, Zorec R. Astrocytes in flavivirus infections. Int J Mol Sci. 2019;20:691.

147. Daniels BP, Holman DW, Cruz-Orengo L, Jujjavarapu H, Durrant DM, Klein RS Viral pathogen-associated molecular patterns regulate blood-brain barrier integrity via competing innate cytokine signals. MBio. 2014;5:1-13.

148. Verma S, Kumar M, Gurjav U, Lum S, Nerurkar VR. Reversal of West Nile virus-induced blood-brain barrier disruption and tight junction proteins degradation by matrix metalloproteinases inhibitor. Virology. Academic Press. 2010;397:130-8.

149. Stefanik M, Formanova $P$, Bily $T$, Vancova $M$, Eyer $L$, Palus $M$, et al. Characterisation of Zika virus infection in primary human astrocytes. BMC Neurosci. BioMed Central. 2018;19:1-8.

150. Chang C-Y, Li J-R, Chen W-Y, Ou Y-C, Lai C-Y, Hu Y-H, et al. Disruption of in vitro endothelial barrier integrity by Japanese encephalitis virus-Infected astrocytes. Glia. 2015;63:1915-32.

151. Bhowmick S, Duseja R, Das S, Appaiahgiri MB, Vrati S, Basu A. Induction of IP-10 (CXCL10) in astrocytes following Japanese encephalitis. Neurosci Lett. 2007:414:45-50

152. Soung A, Klein RS. Viral encephalitis and neurologic diseases: focus on astrocytes. Trends Mol Med. Elsevier Ltd. 2018;24:950-62.

153. Erickson MA, Banks WA. Neuroimmune axes of the blood-brain barriers and blood-brain interfaces: bases for physiological regulation, disease states, and pharmacological interventions. Pharmacol Rev. 2018;70:278-314.

154. Blecharz-Lang KG, Wagner J, Fries A, Nieminen-Kelhä M, Rösner J, Schneider UC, et al. Interleukin 6-mediated endothelial barrier disturbances can be attenuated by blockade of the IL6 receptor expressed in brain microvascular endothelial cells. Transl Stroke Res. 2018;9:631-42.

155. Rustenhoven J, Jansson D, Smyth LC, Dragunow M. Brain pericytes as mediators of neuroinflammation. Trends Pharmacol Sci. 2017;38:291-304.

156. Rudziak P, Ellis CG, Kowalewska PM. Role and molecular mechanisms of pericytes in regulation of leukocyte diapedesis in inflamed tissues. Mediators Inflamm. 2019:2019:1-9.

157. Chang CY, Li JR, Ou YC, Lin SY, Wang YY, Chen WY, et al. Interplay of inflammatory gene expression in pericytes following Japanese encephalitis virus infection. Brain Behav Immun. Elsevier Inc.; 2017;66:230-43.

158. Chen C-J, Ou Y-C, Li J-R, Chang C-Y, Pan H-C, Lai C-Y, et al. Infection of pericytes in vitro by Japanese encephalitis virus disrupts the integrity of the endothelial barrier. J Virol. 2014:88:1150-61.

159. Snyder HM, Corriveau RA, Craft S, Faber JE, Greenberg SM, Knopman D, et al. Vascular contributions to cognitive impairment and dementia including Alzheimer's disease. Alzheimer's Dement. Elsevier. 2015;11:710-7. 
160. Hawkins BT, Davis TP. The blood-brain barrier / neurovascular unit in health and disease. Pharmacol Rev. 2005;57:173-85.

161. Marchi N, Bazarian JJ, Puvenna V, Janigro M, Ghosh C, Zhong J, et al. Consequences of repeated blood-brain barrier disruption in football players. Dhandapani KM, editor. PLoS One. 2013;8:e56805.

162. Stogsdill JA, Eroglu C. The interplay between neurons and glia in synapse development and plasticity. Curr Opin Neurobiol. 2017;42:1-8.

163. Koehl M, Abrous DN. A new chapter in the field of memory: adult hippocampal neurogenesis. Eur J Neurosci. 2011;33:1101-14.

164. Hirano M, Yoshii K, Sakai M, Hasebe R, Ichii O, Kariwa H. Tick-borne flaviviruses alter membrane structure and replicate in dendrites of primary mouse neuronal cultures. J Gen Virol. 2014;95:849-61.

165. Figueiredo CP, Barros-Aragão FGQ, Neris RLS, Frost PS, Soares C, Souza INO, et al. Zika virus replicates in adult human brain tissue and impairs synapses and memory in mice. Nat Commun. Springer US; 2019;10:3890.

166. Nazmi A, Mukhopadhyay R, Dutta K, Basu A. STING mediates neuronal innate immune response following Japanese encephalitis virus infection. Sci Rep. 2012;2:347.

167. Ikegami A, Haruwaka K, Wake H. Microglia: lifelong modulator of neural circuits. Neuropathology. 2019;39:173-80.

168. Azevedo EP, Ledo JH, Barbosa G, Sobrinho M, Diniz L, Fonseca ACC, et al. Activated microglia mediate synapse loss and short-term memory deficits in a mouse model of transthyretin-related oculoleptomeningeal amyloidosis. Cell Death Dis. 2013;4:e789.

169. Rajendran L, Paolicelli RC. Microglia-mediated synapse loss in Alzheimer's disease. J Neurosci. 2018;38:2911-9.

170. Adle-Biassette H, Chrétien F, Wingertsmann L, Héry C, Ereau T, Scaravilli F, et al. Neuronal apoptosis does not correlate with dementia in HIV infection but is related to microglial activation and axonal damage. Neuropathol Appl Neurobiol. 1999;25:123-33.

171. Lum F-M, Low DKS, Fan Y, Tan JJL, Lee B, Chan JKY, et al. Zika virus infects human fetal brain microglia and induces inflammation. Clin Infect Dis. 2017; 64:914-20.

172. Thounaojam MC, Kaushik DK, Kundu K, Basu A. MicroRNA-29b modulates Japanese encephalitis virus-induced microglia activation by targeting tumor necrosis factor alpha-induced protein 3. J Neurochem. John Wiley \& Sons, Ltd (10.1111); 2014;129:143-54.

173. Bhatt RS, Kothari ST, Gohil DJ, D'Souza M, Chowdhary AS. Novel evidence of microglial immune response in impairment of dengue infection of CNS. Immunobiology. 2015;220:1170-6.

174. Chauhan PS, Misra UK, Kalita J, Chandravanshi LP, Khanna VK. Memory and learning seems to be related to cholinergic dysfunction in the JE rat model. Physiol Behav. 2016;156:148-55.

175. Vasek MJ, Garber C, Dorsey D, Durrant DM, Bollman B, Soung A, et al. A complement-microglial axis drives synapse loss during virus-induced memory impairment. Nature. 2016;534:538-43.

176. Garber C, Soung A, Vollmer LL, Kanmogne M, Last A, Brown J, et al. T cells promote microglia-mediated synaptic elimination and cognitive dysfunction during recovery from neuropathogenic flaviviruses. Nat Neurosci. Springer US. 2019;22

177. J T-G, M G. Microglia in memory decline from Zika virus and West Nile virus infection. Trends Neurosci. Trends Neurosci; 2019;42.

178. Garber C, Vasek MJ, Vollmer LL, Sun T, Jiang X, Klein RS. Astrocytes decrease adult neurogenesis during virus-induced memory dysfunction via IL-1 article. Nat Immunol. 2018:19:151-61.

179. Sher AA, Glover KKM, Coombs KM. Zika virus infection disrupts astrocytic proteins involved in synapse control and axon guidance. Front Microbiol. Frontiers Media SA; 2019;10:596.

180. Li H, Saucedo-Cuevas L, Regla-Nava JA, Chai G, Sheets N, Tang W, et al. Zika virus infects neural progenitors in the adult mouse brain and alters proliferation. Cell Stem Cell. Elsevier Inc.; 2016;19:593-8.

181. Kohman $\mathrm{R}$ a, Rhodes JS. Neurogenesis, inflammation and behavior. Brain Behav Immun. Elsevier Inc.; 2013;27:22-32.

182. Fagiolini $\mathrm{M}$, Jensen $\mathrm{CL}$, Champagne $\mathrm{F}$. a. Epigenetic influences on brain development and plasticity. Curr Opin Neurobiol. Elsevier Ltd. 2009;19: 207-12

183. Christopher MA, Kyle SM, Katz DJ. Neuroepigenetic mechanisms in disease. Epigenetics Chromatin. BioMed Central; 2017;10:47.

184. Janssens S, Schotsaert M, Karnik R, Balasubramaniam V, Dejosez M, Meissner A, et al. Zika virus alters DNA methylation of neural genes in an organoid model of the developing human brain. Gilbert JA, editor. mSystems. 2018;3.
185. Garcez PP, Correia Loiola E, Madeiro da Costa R, Higa LM, Trindade P, Delvecchio $R$, et al. Zika virus impairs growth in human neurospheres and brain organoids. Science (80- ). 2016;352:816-8.

186. Garcez PP, Minardi J, Mota J, Vasc D, Madeiro R, Delvecchio R, et al. Zika virus disrupts molecular fingerprinting of human neurospheres. Sci Rep. 2016:1-10.

187. Szulwach KE, Li X, Li Y, Song C-X, Wu H, Dai Q, et al. 5-hmC-mediated epigenetic dynamics during postnatal neurodevelopment and aging. Nat Neurosci. 2011;14:1607-16

188. Eldin P, Papon L, Oteiza A, Brocchi E, Lawson TG, Mechti N. TRIM22 E3 ubiquitin ligase activity is required to mediate antiviral activity against encephalomyocarditis virus. J Gen Virol. 2009;90:536-45.

189. Nisole S, Stoye JP, Saïb A. TRIM family proteins: retroviral restriction and antiviral defence. Nat Rev Microbiol. 2005;3:799-808.

190. Gokhale NS, McIntyre ABR, McFadden MJ, Roder AE, Kennedy EM, Gandara JA, et al. N6-methyladenosine in Flaviviridae viral RNA genomes regulates infection. Cell Host Microbe. 2016;20:654-65.

191. Lichinchi G, Zhao BS, Wu Y, Lu Z, Qin Y, He C, et al. Dynamics of human and viral RNA methylation during Zika virus infection. Cell Host Microbe. 2016:20:666-73.

192. Gokhale NS, Mclntyre ABR, Mattocks MD, Holley CL, Lazear HM, Mason CE, et al. Altered m6A modification of specific cellular transcripts affects Flaviviridae infection. Mol Cell: Cell Press; 2019

193. Mclntyre W, Netzband R, Bonenfant G, Biegel JM, Miller C, Fuchs G, et al. Positive-sense RNA viruses reveal the complexity and dynamics of the cellular and viral epitranscriptomes during infection. Nucleic Acids Res. 2018; 46:5776-91.

194. Hyde JL, Diamond MS. Innate immune restriction and antagonism of viral RNA lacking 2'-O methylation. Virology. 2015;479-480:66-74.

195. Fourrier C, Singhal G, Baune BT. Neuroinflammation and cognition across psychiatric conditions. CNS Spectr. 2019;24:4-15.

\section{Publisher's Note}

Springer Nature remains neutral with regard to jurisdictional claims in published maps and institutional affiliations.
Ready to submit your research? Choose BMC and benefit from:

- fast, convenient online submission

- thorough peer review by experienced researchers in your field

- rapid publication on acceptance

- support for research data, including large and complex data types

- gold Open Access which fosters wider collaboration and increased citations

- maximum visibility for your research: over $100 \mathrm{M}$ website views per year

At BMC, research is always in progress.

Learn more biomedcentral.com/submissions 